\title{
The Impact of Street and Food Festivals in Gastronomic Tourism through Visitor's Emotions and Satisfaction. A Case of Abu Dhabi Food Festival
}

\author{
Dr. Almaz Sandybayev* \\ Assistant Prof., Higher Colleges of Technology, Abu Dhabi Men's College, Faculty of Business, United Arab \\ Emirates
}

*Corresponding Author: Dr. Almaz Sandybayev, Assistant Prof., Higher Colleges of Technology, Abu Dhabi Men's College, Faculty of Business, United Arab Emirates

\begin{abstract}
Gastronomic tourism is a new trend in the development of world tourism which may serve as a fuel for development of economy, cultural heritage and sustainable tourism growth. The research paper aims to analyze the impacts of street food festivals by exemplifying the role of visitors through emotions and satisfaction factors. The study has been focused on food truck festival in Abu Dhabi (the United Arab Emirates) in March-April 2017 that attracted over 150 vendors - food tents, food trucks and local businesses. 320 random participants have been assessed through a questionnaire during one week to test how location and satisfaction impacts on them. The results implication proved that satisfaction positively impacts on visitor's behaviors and behavioral intention. Every gastronomic and culinary experience is a memory of the destination, every smell and taste strengthens and restores memories of the place. Consequently, food and location are linked together, forming the basis that is included in the modern development of the economy of impressions and gives the opportunity to see a new version of the use of environment.
\end{abstract}

Keywords: Gastronomic Tourism, Destination/Place, Emotion, Satisfaction, Abu Dhabi.

\section{INTRODUCTION}

Culinary traditions of the countries in the world have been laid down for centuries, as they were influenced by a large number of factors, including the influence of climatic conditions and geographical location, economic well-being of countries and the degree of influence of other cultures. Gradually the ethnos of the country has been formed and as a consequence of this process the formation of gastronomic features. When it comes to get acquainted with any country, the first to come across is its culture. Undoubtedly, the food and rituals of its adoption are the most important elements of the material culture of any nation. This statement is proved at least by the fact that people, being naturally omnivores, eat differently in different national cultures. There is awell-known statement, to know better the culture of the country - taste it. It is with this goal in mind that the new trend of tourism is a culinary tourism that has taken a shape recently and emerged into a phenomenon of gastronomic tourism. This phenomenon has been widely discussed (Hall, Sharples, Mitchell, Macionis, and Cambourne, 2003; Hjalager and Richards, 2002; Honggen and Smith, 2008; Long, 2004; Wolf, 2002). According to Quan and Wang 2004, gastronomic tourism is an emerging phenomenon that is being developed as a new tourism product, due to the fact that over a third of tourist spending is devoted to food. Wolf (2002) pointed out that gastronomic tourism motivates tourists to enjoy both food and unforgettable dining experience at the same time. In this sense, destination and location play a significant role presenting gastronomic tourism as a key factor in the competitiveness of tourist destinations through motivating tourists and in determining their choice (Henderson, 2009). As a result, tasting local foods has formed an important path to enjoy the local culture (Long, 2004), where Cohen and Avieli (2004) argue that local foods might be an attraction or impediment to tourist experience. Within this framework, it becomes important to differentiate the bridge between nature and the motives of human being and gastronomic experiences effecting factors like emotions and satisfaction. Schmitt (1999 and 2003) discussed the role of a holistic experience which resulted from the interaction of sensorial (sense), affective (feel), cognitive (think), behavioral (act) and social (relate) experiences. 
Thus, the aim of the paper is to analyze which role gastronomic tourism plays and how it is impacted by understanding the key motivators of the visitor and determining their choice of destination (Henderson, 2009). Another key objective is to identify visitor's perception namely emotions and satisfaction contributing to the positive or negative image created by a destination strategy. As a result, it might be helpful for the gastronomic and touristic organizations to form destination's positioning strategy (Ibrahim and Gill, 2005; Kivela and Crotts, 2006).

\section{LITERATURE REVIEW}

\subsection{Gastronomic Tourism}

Gastronomic culture is a culturally specific system of norms, principles and patterns, embodied in (a) cooking methods, (b) a set of products accepted in a given culture and their combinations, (c) food consumption practices, and (d) overall reflexing over cooking processes and eating. The application of this concept in cultural studies of food allows to give a structured description of food norms and their historical, cultural and social conditioning, as well as to analyze the mechanisms of its distribution and functioning in different cultural and historical conditions. As specified by numerous authors, in order for tourism to develop in an area; depends on the society's acceptance and efficient consume of local traditions and sources (Eadington and Redman, 1991; Gezici, 1998; Williams and Shaw, 1995).

The importance of of culinary tourism was put forward and defined by Long (2004) as a global activity in which people participate in "other" food culture, including tasting, consumption, preparation and display food. Smith and Xiao (2008) agree that gastronomic tourism is a result of tourists experience from appreciation and consumption of local food. They conceptualize the idea that tourists are seeking unique food experience while on vacation. Wolf (2002) emphasized the relation how motivation effects on tourists, when according to Hall et al. (2003: p. 308), food tourism is defined as a type of tourism to attract tourists and make them to visit food producers, participate in the gastronomic festivals and have dining experience. Thus, it is possible to admit that the purpose of gastronomic tourism is to enjoy the specialties of the cuisine of a particular country through unforgettable experience of enjoying the local recipes which for centuries absorbed the traditions and customs of the local people and their culture of cooking.

\subsection{Food Festival}

The gastronomic tourism experience has been assessed as having multiple valuable effects on the territory and its products. As noted by Corigliano (2002), gastronomic tourism searches for the local food resources together with cultural and environmental factors, considering the number of players involved as hotels, travel agencies, restaurants, bars etc.

In this regard, attending food festivals and gastronomic events have become interesting activity (Hall et al., 2003: pp. 102-120). As noted by Gibson and Kong, 2005; McCann, 2002, local cultural food festivals are impacting both on culture and economy. It is suggested, that festivals and food place activities create an enormous opportunity for businesses and generate income as well as revenue of the state (Huang et al., 2010; Dwyer et al., 2005). From another point of view, festivals and social activities effect on society sustainability in regions and small towns (O'Sullivan and Jackson, 2002). As a result, it stimulates creative interventions and planning activities that can affect local development and regeneration processes (Klaic, 2002).

\subsection{Emotion and Satisfaction}

Motivational factors for the gastronomic consumptions have an important influx on tourist's behaviors and choices. Fields (2002) described the role of four factors attributed to motivation in food consumption. Kim et al. (2009) has pointed out to the fact of using grounded theory and proposed motivational factors including, demography and physiologic. Among those factors are: surrounding atmosphere, prestige and status, sensory and sensual experience, authentic and exciting experience.

According to the authors Havlena and Holbrook (1986), experiential consumption is the main factor that has an emotional nature. Consequently, the environment and surrounding may affect perceptions and affective responses. Environmental factors perceived by an individual refer to both visible and invisible stimuli, as an example to taste (Ulrich, 1983). Pleasure of food consumption and its emotional condition relates to feeling happiness or joy, stimulating involvement, excitement, 
stimulation feelings. In addition, in case of gastronomic festival events, it is also entitled to classify emotional experiences respectively relating to products and events, with a purpose to find out potentially effect it may have (Rigatti Luchini and Mason, 2010).

An exquisite taste in food and an understanding of the subtleties of culinary art is all gastronomy. Its goal not only to satisfy physiological needs but also to give a feeling of pleasure. Homburg and Giering (2001) discovered that satisfaction is correlated to service evaluation and total experience. According to Jamal 2004, satisfaction has been considered one of the key research fields in marketing and consumer behavior. Consumer satisfaction definitions have either emphasized an evaluation process (e.g., Fornell 1992; Hunt 1977) or a response to an evaluation process (e.g., Halstead, Hartman, and Schmidt 1994; Howard and Sheth 1969; Oliver 1997; Tse and Wilton 1988).Different authors, stress importance on the fact of relation between satisfaction and emotional as a cognitive construction (Babin and Griffin, 1998; Bagozzi, 1991). Oliver, Rust, and Varki (1997) found that positive emotions characterize higher customer satisfaction. Consequently, two main concepts in cognitive feeling, emotion and satisfaction will be tested through this research.

\subsection{The United Arab Emirates Gastronomic Trend}

Gastronomic tourism has proved to be a rather profitable income of the state's economy and not surprisingly that a number of countries started to develop this trend even not been famous for its gastronomic culture. All countries have equal conditions for the development of culinary tourism and this is a unique distinctive feature of this type of tourism. Specific events and gastronomic festivals which are periodically held around the world are very popular among tourists. For example, September is the time of the Oyster Festival in Ireland and the Oktoberfest in Munich, July, traditionally hosts the festival of Spanish national food San Fermin and Bonton - a tuna festival in Italy, November is famous for Beaujolais Nouveau - a festival of young wine in France.

The United Arab Emirati cousin is considered one of the most delicious and refined traditional cuisines in the world through which the people express their benevolence and generosity. Abu Dhabi as a capital city hosts numerous food events and festivals during a year. One of the most famous is Abu Dhabi Food Festival (ADFF) in December. Spread over 19 days, ADFF attracts foodies, families and friends to enjoy not only cuisine from some of the best chefs but also some of the most scrumptious street food available anywhere in the world today. Another event, Gourmet Abu Dhabi features exceptional food experiences in a variety of world-class venues. Master Chef Events from all parts of the world and Street Feasts are aiming to provide culinary experience and well known as fastest-growing food, beverage and hospitality event in the MENA region.

\section{METHODS}

The proposed model has been tested through empirical approach on a sample of 320 random attendees visiting 2017 Abu Dhabi Food Festival. Mobile food trucks were the main attraction for the gourmets. The festival reached out to residents and visitors and creates a growing interest by an increasing number of attendees every year. The questionnaires was randomly sampled and consisted 5-point Likert scale. As seen from Table 1, demographic characteristics.

Table1. Demographic and descriptive characteristics of visitors (N 320)

\begin{tabular}{|c|c|c|}
\hline Demographics & Frequency (N) & Percent (\%) \\
\hline \multicolumn{3}{|c|}{ Gender } \\
\hline Male & 175 & 54.69 \\
\hline Female & 14545.31 & 100 \\
\hline Total & 320 & 30.00 \\
\hline Under 30 & Age Category & 46.25 \\
\hline Between 30-40 & 96 & 23.75 \\
\hline Above 40 & 148 & \\
\hline
\end{tabular}

Exploratory analysis proposed to focus on 2 key criteria of emotion and satisfaction. Together with the choice of a 5-point Likert scale, this also has the advantage of justifying the use of structural models for continuous variables. Table 2 indicates two indexes of emotional satisfaction and evaluative satisfaction, characterized by high levels ofCronbach's Alpha and the principal component 
The Impact of Street and Food Festivals in Gastronomic Tourism through Visitor's Emotions and Satisfaction. A Case of Abu Dhabi Food Festival

analysis indicating one only eigenvalue higher than 1 , with factor loadings reported in the last column of Table 2 .

Table2. Descriptive statistics, Cronbach's Alpha (indicators) and factor loadings (items)

\begin{tabular}{|l|l|l|l|l|}
\hline \multicolumn{1}{|c|}{ Indicator } & \multicolumn{1}{c|}{ Mean } & \multicolumn{1}{c|}{ SD } & Alpha & Loading \\
\hline Emotional Satisfaction & $\mathbf{5 . 6 5}$ & $\mathbf{1 . 7 1}$ & $\mathbf{0 . 8 2}$ & \\
\hline \multicolumn{1}{|c|}{ SFF makes me happy } & 5.35 & 1.61 & & 0.82 \\
\hline SFF gives me enjoy & 5.75 & 1.60 & & 0.90 \\
\hline SFF provides me enjoy from shows & 5.22 & 1.44 & & 0.80 \\
\hline SFF gives me a pleasant feeling & 5.45 & 1.70 & & 0.84 \\
\hline Evaluative Satisfaction & $\mathbf{5 . 3 5}$ & $\mathbf{1 . 2 1}$ & $\mathbf{0 . 8 3}$ & \\
\hline SFF provides me what I was looking for & 5.17 & 1.49 & & 0.80 \\
\hline SFF satisfies my expectations & 5.12 & 1.51 & & 0.75 \\
\hline SFF gives me high satisfaction & 5.05 & 1.56 & & 0.78 \\
\hline \multicolumn{1}{|l|}{ SFF is a great experience } & 5.28 & 1.62 & & 0.81 \\
\hline
\end{tabular}

$*(p>.05)$

*SFF - Street Food Festival

\section{Results}

The level of emotional and evaluative satisfaction reported by food tourists in relation to a street food festival is significantly high. Utilizing a 5 -point Likert Scale $(1=$ very dissatisfied, $5=$ very satisfied $)$, all questions been presented at levels 4 and 5, with an average of 5.34. This preliminary signals that the Street Food Festival is asignificant event where visitors and guests reported as being satisfied or very satisfied. $92 \%$ of all respondents informed to be satisfied and happy with the event. There is a symbolic correlation between the level of satisfaction with the age. The middle age group (30-40 yrs.) expressed more satisfaction comparing to other age groups about SFF. In sum, the idea of street festivals forms a great opportunity and impacts positively on satisfaction of the visitors.

Another important factor is in the face of increasing competition in the sphere of tourism and its marketing, each region is in search of unique products. Local Arab cuisine is already a platform that contains the necessary resources that can be used as a marketing tool to attract customers, promote cities, regions and even entire countries. Abu Dhabi as a capital city of the UAE is an important source of sustainable gastronomic tourism. Investing into this trends has a huge strategic advantage.

\section{DISCUSSION}

The paper aimed to empirically analyze the role of Street Food Festivals through satisfaction and emotion indicators during Abu Dhabi Food Festival in December. The study tried to discover the nature of satisfaction and emotion of the visitor to attend this event. 320 participants were examined through a questionnaire. Based on this observation, behavioral intention was not only a satisfaction reasonbut it is also connects to psychologicaland emotional aspect. In this context, the paper focused to evaluate the relations between SFF as a place and visitor's emotional condition. The results from analysis highlight a direct positive impact that street food festivals and its types have on emotional and satisfaction experience components. In the view of considering place (SFF), it is possible to conclude that emotional and satisfaction aspects regulate the positive rapport between place and intention. Obviously, it could be a significant tool to affect behavioral intentions by creating the atmosphere of fun, joy and happiness which impacts on emotions of the visitor. Thus, creating positive emotional background with a positive experience for the visitors certainly influence on satisfaction and behavioral intentions of festival visitors.

\section{CONCLUSION}

The development of gastronomic tourism can be a promising area for any region and country, even without significant tourist resources. Destination and place can be considered as a great element of attracting gastronomic tourists. Food events and Festivals are a source catalyzers for a better performance and tourism development. Thus, the study focused not only on investigating elements of satisfaction from the visitor's side but also to develop a sociocultural view and the specifics of the representation forms of gastronomic culture. The culture produces deeper knowledge about the 
mechanisms of functioning of the culture of everyday life to clarify a number of general questions of theory and the history. The analysis of gastronomic culture allows to reach out to more global issues of identity formation, the translation of norms and values, the peculiarities of Arab culture and not only. This suggestion confirms the fact that, gastronomic tourism can become the basis for the development of tourism in many national regions of the United Arab Emirates and serve as great example for other regions.

\section{REFERENCE}

[1] Babin, B. J., and Griffin, M. (1998). The nature of satisfaction: an updated examination and analysis. Journal of Business Research, 41, 127-36.

[2] Bagozzi, R. P. (1991). Further thoughts on the validity of measures of elation, gladness, and joy. Journal of Personality and Social Psychology, 61, 98-104.

[3] Cohen, E., and Avieli, N. (2004). Food in Tourism: Attraction and Impediment. Annals of Tourism Research, 4, 755-778. http://dx.doi.org/10.1016/j.annals.2010.03.007

[4] Corigliano, M. A. (2002), "The route to quality: Italian gastronomy networks in operation", In: Hjalager A M. and Richards G. (Eds.), Tourism and Gastronomy Routledge, London: 166-185

[5] Eadington, W.R., Redman, M. (1991). Economics and Tourism. Annals of Tourism Research, 18(1), 4156.

[6] Dwyer, L., Forsyth, P. and Spurr, R. (2005). Estimating the impacts of special events on an economy. Journal of Travel Research, 43(4), 351-359.

[7] Fornell, Claes. 1992. "A National Customer Satisfaction Barometer: The Swedish Experience." Journal of Marketing 56 (1): 6-21.

[8] Gezici, F. (1998). Sürdürülebilir Bölgesel Kalkınma Amacında Turizm Eylemlerinin Etkisi: Türkiye Üzerine Karşılaştırmalı Bir Araştırma. Doktora Tezi (PhD thesis), İstanbul: İstanbul Teknik Üniversitesi Fen Bilimleri Enstitüsü.

[9] Gibson, C. and Kong, L. (2005). Cultural economy: a critical review. Progress in Human Geography, 29(5), 541-61

[10] Homburg, C., and Giering, A. (2001). Personal characteristics as moderators of the relationship between customer satisfaction and loyalty e an empirical analysis. Psychology \& Marketing, 18(1), 43-66.

[11] Hunt, H. Keith. 1977. "CS/D--Overview and Future Research Direction." in Conceptualization and Measurement of Consumer Satisfaction and Dissatisfaction. H. Keith Hunt, ed. Cambridge, MA: Marketing Science Institute.

[12] Halstead Diane, David Hartman, and Sandra L. Schmidt. 1994. "Multisource Effects on the Satisfaction Formation Process." Journal of the Academy of Marketing Science 22 (Spring): 114-129

[13] Hall, C. M., Sharples, L., Mitchell, R., Macionis, N., \& Cambourne, B. (2003). Food tourism around the world: Development, management and markets. Oxford: Butterworth-Heinemann.

[14] Hjalager, A., and Richards, G. (2002). Tourism and gastronomy. London: Routledge.

[15] Honggen, X., and Smith, S. (2008). Culinary tourism supply chains: a preliminary examination. Journal of Travel Research, 46(3), 289-299.

[16] Henderson, J C. (2009), “Food tourism reviewed", British Food Journal, 11 (4): 317-326.

[17] Huang, J.Z., Li, M. and Cai, L.A. (2010). A model of community-based festival image. International Journal of Hospitality Management, 29(2), 254-260

[18] Havlena, W. J., and Holbrook, M. B. (1986). The varieties of consumption experience: comparing two typologies of emotion in consumer behavior. Journal of Consumer Research, 13, 394e404.

[19] Kivela, J., \& Crotts, J. C. (2006). Tourism and Gastronomy: Gastronomy's Influence on How Tourists Experience a Destination. Journal of Hospitality and Tourism Research, 30 (3): 354-377.

[20] Klaic, D. (2002). Challenges and strategies in festivals: challenges of growth, distinction, support base and internationalization. Tartu: Department of Culture of the Tartu City Government.

[21] Long, L. (2004). Culinary Tourism (Material Worlds). Lexington, KY: The University Press of Kentucky.

[22] McCann, E. (2002). The cultural politics of local economic development: meaning-making, place-making, and the urban policy process. Geoforum, 33, 385-98.

[23] O'Sullivan, D. and Jackson, M. (2002). Festival tourism: a contributor to sustainable local economic development? Journal of Sustainable Tourism, 10(4), 325-342.

[24] Oliver, Richard L. 1997. Satisfaction: A Behavioral Perspective on the Consumer. New York: The McGraw-Hill Companies, Inc. 
The Impact of Street and Food Festivals in Gastronomic Tourism through Visitor's Emotions and Satisfaction. A Case of Abu Dhabi Food Festival

[25] Oliver, R. L., Rust, R. T., and Varki, S. (1997). Customer delight: foundations, findings, and managerial insight. Journal of Retailing, 73(3), 311-336.

[26] Ibrahim, E. E., and Gill, J. (2005). A positioning strategy for a tourist destination, based on analysis of customers' perceptions and satisfactions. Marketing Intelligence and Planning, 23 (2), 172-188.

[27] Quan, Shuai and Wang Ning. "Towards a structural model of the tourist experience: an illustration from food experiences in tourism." Tourism Management 28 (3) (2004): 297-305.

[28] Rigatti Luchini, S., and Mason, M. C. (2010). An empirical assessment of the effects of quality, value and customer satisfaction on consumer behavioral intentions in food events. International Journal of Event Management Research, 5(1), 46-61.

[29] Schmitt, B. H. (1999). Experiential marketing. New York: The Free Press.

[30] Schmitt, B. H. (2003). Customer experience management. Hoboken, NJ: Wiley \& Sons.

[31] Smith, S. L. J., and Xiao, H. G. (2008). Culinary Tourism Supply Chains: A Preliminary Examination. Journal of Travel Research,46, 289-299. http://dx.doi.org/10.1177/004728750 6303981

[32] Tse, David K. and Peter C. Wilton. 1988. "Models of Consumer Satisfaction: An Extension," Journal of Marketing Research, 25 (5): 204-212.

[33] Ulrich, R. S. (1983). Aesthetic and affective response to natural environments. In Altman, I., \& Wohlwill, J. F. (Eds.). (1983). Human behavior and environment: Advances in theory and research, behavior and the natural environment, Vol. 6 (pp. 85-125). New York: Plenum.

[34] Wolf, E. (2002). Culinary tourism: A tasty economic proposition. Portland: International Culinary Tourism Task Force.

[35] Williams, A.M. and Shaw, G. 1995. Tourism and regional development: polari- sation and new forms of production in the UK. Tijdschrift voor Economische en Sociale Geograe 86: 50-63.

Citation: Dr. Almaz Sandybayev. "The Impact of Street and Food Festivals in Gastronomic Tourism through Visitor's Emotions and Satisfaction. A Case of Abu Dhabi Food Festival" International Journal of Research in Tourism and Hospitality (IJRTH), vol 4, no. 1, 2018, pp. 27-32. doi:http://dx.doi.org/10.20431/24550043.0401004 .

Copyright: (C) 2018 Authors. This is an open-access article distributed under the terms of the Creative Commons Attribution License, which permits unrestricted use, distribution, and reproduction in any medium, provided the original author and source are credited. 